\title{
URICOSURIC AGENTS IN THE TREATMENT OF GOUT
}

\author{
BY \\ G. D. KERSLEY AND A. R. GIBBS \\ Royal National Hospital for Rheumatic Diseases, Bath, Somerset
}

During the past $2 \frac{1}{2}$ years an attempt has been made to assess the relative value and toxicity of various uricosuric agents.

\section{Previous Investigations}

Kersley, Cook, and Tovey (1958) reported the therapeutic value of G.28 315 (sulphinpyrazone), a phenylbutazone derivative now known as Anturan (Geigy), in a group of fifteen patients with gout in a clinical trial lasting 3 to 8 months. Benemid and Longacid (Urelim), a benemid-like drug (Ward, Blenkinsop and Co.), were also given in selected cases. The results, as shown by estimations of the urinary uric acid excretion and the serum uric acid, are summarized in the Table (Rows 1-4). Anturan was the most efficacious drug, although the other two also had a definite uricosuric effect. Intermittent administration 3 days per week was not effective. It was found that the use of $3.5 \mathrm{~g}$. aspirin as an analgesic completely inhibited the effect of Anturan in the doses given (Table, Row 5).

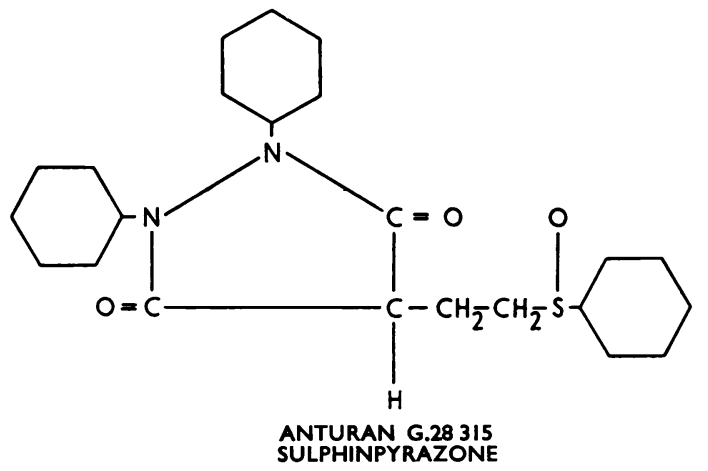

\section{Present Study}

Material.-32 patients were all suffering from typical gout, with raised serum uric acid levels and normal differential agglutination tests. The average age was 56 years. The average age at onset was 41 years (range 22 to 71), fourteen being aged 25 to 35 years at onset. There were 27 men and five women. Thirteen patients gave a definite family history of gout.

Medication.-Each patient had a period on both Anturan and Urelim. Nine had Anturan and two Urelim continuously for more than a year, and the remaining 21 received the two drugs alternately. In eighteen cases Anturan and Urelim were tried together and separately, and in the same group a third drug, Zoxazolamine (Flexin; 2-amino-5-chlorobenzoxazole), was also tried separately.

The chemical structure of all these drugs is shown in the Figure.

In view of our previous finding that $3.5 \mathrm{~g}$. aspirin given simultaneously with Anturan completely
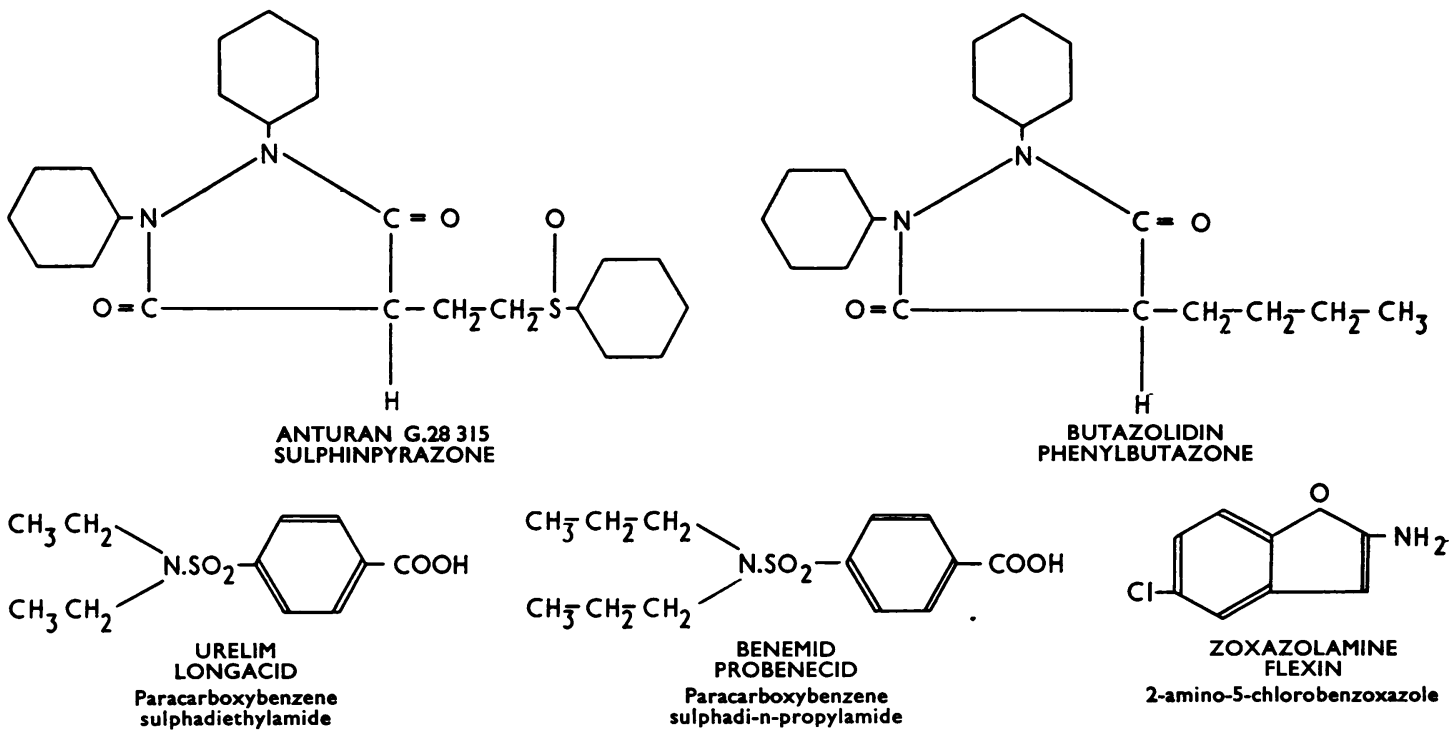

Figure.-Chemical formulae of uricosuric agents used in this trial. 
inhibited the uricosuric effect of the latter, the results were observed of giving aspirin or paracetamol* to four patients who were taking Anturan regularly, and to one who was taking Zoxazolamine.

Further investigations included the effects of Anturan and Zoxazolamine on the serum cholesterol and prothrombin times.

\section{Results}

Anturan.- The patients who continued on Anturan continued to do well, the serum uric acid levels remaining the same at the end of one year as they had been at the end of 3 months. In the patients shown in the Table (Row 4) in whom the average serum uric acid level was $7 \cdot 1$ $\mathrm{mg} . / 100 \mathrm{ml}$. before treatment and $4.8 \mathrm{mg}$./ $100 \mathrm{ml}$. at the end of 3 months, the level was $4.9 \mathrm{mg}$. $/ 100 \mathrm{ml}$. after one year.

Anturan + Urelim.-Eighteen patients who were taking Anturan $400 \mathrm{mg}$. daily regularly for

Panok, Panadol. some months were given in addition $1.5 \mathrm{~g}$. Urelim daily for one week, and the Urelim was continued at the same dosage for a furthero? week while the Anturan was reduced to $200 \mathrm{mg} . \vec{\Rightarrow}$ daily. The average daily serum uric acid level was $3.5 \mathrm{mg} . / 100 \mathrm{ml}$. on Anturan alone, fell to을 $2.9 \mathrm{mg} . / 100 \mathrm{ml}$. when Urelim was added, and $\frac{\overline{\bar{O}}}{\mathrm{n}}$ rose to $3.1 \mathrm{mg} . / 100 \mathrm{ml}$. when the Anturan $\frac{\bar{\sigma}}{\widehat{D}}$ was reduced (Table, Rows 7-9). Meanwhile, $\stackrel{\varnothing}{\varrho}$ the average daily urinary uric acid excretion rose from 776 to 806 , and then fell to $654 \mathrm{mg}$./ $\vec{\circ}$ $100 \mathrm{ml}$. The results suggest that Urelim had an adjuvant effect in combination with Anturan. $\overrightarrow{\vec{\omega}}$

Urelim.-This drug was also tried alone in seven $\frac{\stackrel{2}{2}}{2}$ patients, who received $1.5 \mathrm{~g}$. daily. Their $\frac{\overrightarrow{0}}{0}$ average urinary uric acid excretion (which had ${ }_{\oplus}$ been $608 \mathrm{mg}$./day before treatment) rose to $\omega$ $880 \mathrm{mg}$./day, and the serum uric acid level $(7.8 \mathrm{mg} . / 100 \mathrm{ml}$. before treatment) fell to을 $6.4 \mathrm{mg} . / 100 \mathrm{ml}$. (Table, Row 6). Thus Urelim was not so effective alone as with Anturan.

TABLE

RESULTS OF PREVIOUS INVESTIGATION AND PRESENT STUDY

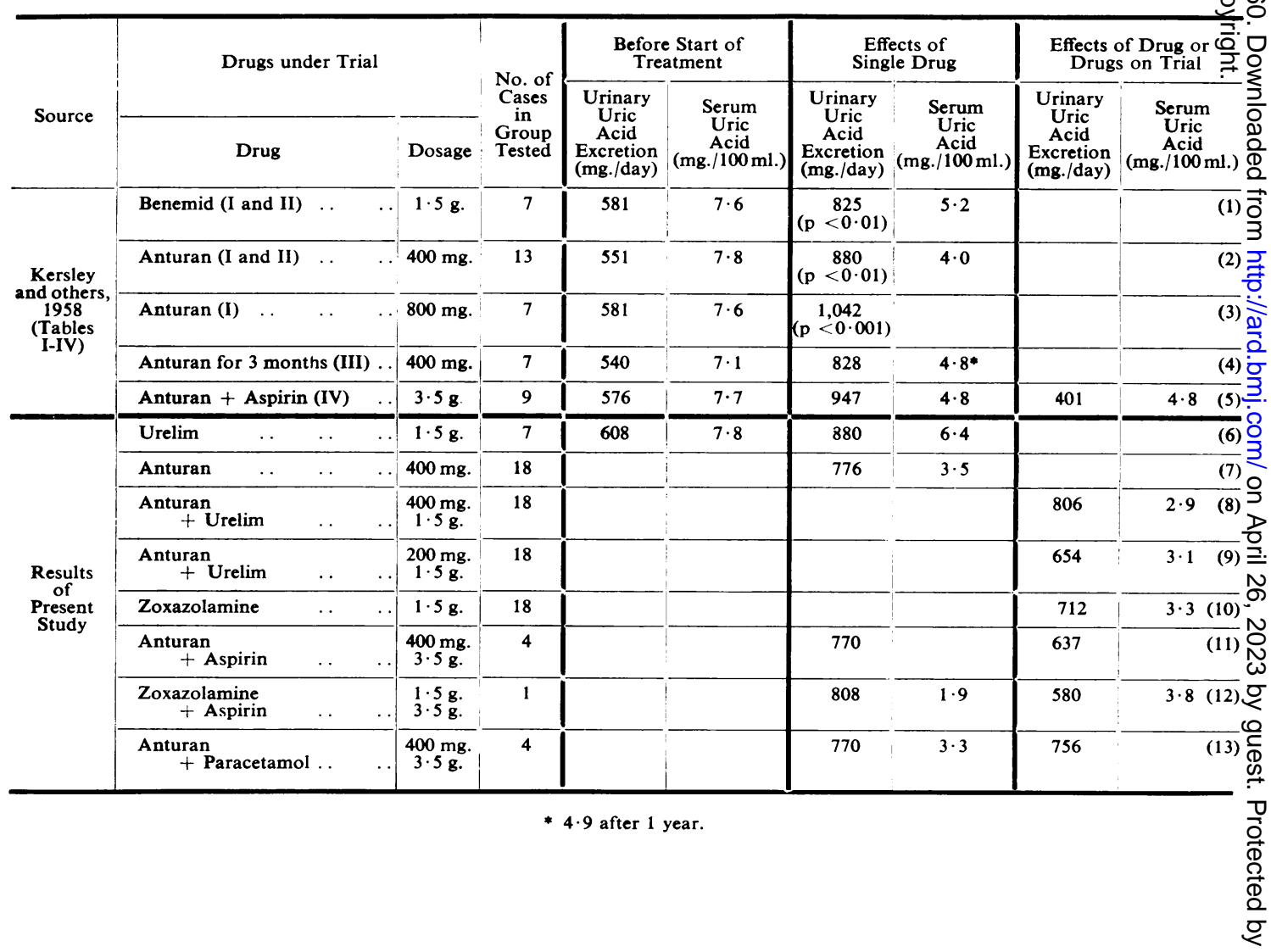


Zoxazolamine.-This drug was originally produced as a relaxant, depressing the subcortical and spinal pathways (Lancet, 1956). A dose of $0.25 \mathrm{~g}$. was said to promote uricosuria by Burns, Yü, Berger, and Gutman (1958) and Reed, Feichtmeir, and Willett (1958), and its effect was therefore compared with that of Anturan and Urelim. The same eighteen patients who had been taking Anturan $400 \mathrm{mg}$. daily regularly for some months were given Zoxazolamine $1.5 \mathrm{~g}$. daily for one week. The average daily serum uric acid level fell from 3.5 to $3.3 \mathrm{mg} . / 100 \mathrm{ml}$., but at the same time the average daily urinary uric acid excretion fell from 776 to $712 \mathrm{mg}$. (Table, Row 10).

\section{Addition of Analgesics}

Aspirin.-Four patients who were taking Anturan $400 \mathrm{mg}$. daily regularly were given $3.5 \mathrm{~g}$. aspirin in addition, and the average daily urinary uric acid excretion fell from 770 to $637 \mathrm{mg}$. (Table, Row 11).

One patient who had taken Zoxazolamine $1.5 \mathrm{~g}$. for one week was given $3.5 \mathrm{~g}$. aspirin in addition for a further week, and the daily urinary uric acid excretion fell from 808 to $580 \mathrm{mg}$., while the serum uric acid level rose from 1.9 to $3.8 \mathrm{mg} . / 100 \mathrm{ml}$. (Table, Row 12).

Paracetamol (N-acetyl-p-amino-phenol; Panadol, Panok).- The four patients on Anturan who had been tested with additional aspirin were also tested with additional paracetamol $3.5 \mathrm{~g}$. daily, and the average daily urinary uric acid excretion fell only very slightly from 770 to $756 \mathrm{mg}$. (Table, Row 13).

The question of analgesics is important in a case presenting both gout and osteo-arthritis, and it appears that paracetamol can be combined with a uricosuric agent without significantly inhibiting the effect of the latter.

\section{Effect of Uricosuric Agents on Blood Coagulation and Serum Cholesterol.}

Thompson, Mikkelsen, and Willis (1959), who reviewed the uricosuric effect of various anticoagulants, found that ethylbicoumacetate (Tromexan), bihydroxycoumarin, and anisindione produced uricosuria.

Kohn and Prozan (1959), who found that a series of patients with acute myocardial infarction had serum uric acid levels above $6 \mathrm{mg} . / 100 \mathrm{ml}$., suggested that the exhibition of uricosuric drugs might afford some protection against coronary atherosclerosis.

Gertler and White (1954) has suggested that high serum uric acid levels might encourage the deposition of cholesterol, so that a lowering of the serum uric acid level might improve the prognosis by counteracting this process.

Serum cholesterol levels and prothrombin times were estimated in our gouty patients while under treatment with uricosuric agents.

Serum Cholesterol.-There is a wide variation in normal levels which average about $200 \mathrm{mg}$. per cent., the range according to Juergens and Achor (1959) being $150-250 \mathrm{mg}$. per cent. Treatment by restriction of fats and the use of oestrogens or thyroid extract has been advised for patients with levels above $250 \mathrm{mg}$. per cent.

Our eighty serum cholesterol estimations showed no direct correlation between the levels of cholesterol and uric acid. In thirty estimations on patients in whom the average serum uric acid level was below $3.5 \mathrm{mg} . / 100 \mathrm{ml}$., the average serum cholesterol was $241 \mathrm{mg}$. per cent., and in twelve estimations on patients in whom the average serum uric acid level was above $4.5 \mathrm{mg} . / 100 \mathrm{ml}$, , the average serum cholesterol was $232 \mathrm{mg}$. per cent. In four cases for which figures were available before and after treatment, however, there was a tendency for the serum cholesterol to fall as the serum uric acid fell:

\begin{tabular}{l|c|c|c|c}
\hline \multirow{2}{*}{$\begin{array}{l}\text { Case } \\
\text { No. }\end{array}$} & \multicolumn{2}{|c|}{$\begin{array}{c}\text { Serum Uric Acid } \\
\text { (mg./100 ml.) }\end{array}$} & \multicolumn{2}{|c}{$\begin{array}{c}\text { Serum Cholesterol } \\
\text { (mg. per cent.) }\end{array}$} \\
\cline { 2 - 3 } & Before & After & Before & After \\
\hline 1 & $7 \cdot 3$ & $3 \cdot 6$ & 210 & 200 \\
2 & $5 \cdot 2$ & $2 \cdot 8$ & 284 & 225 \\
3 & $7 \cdot 9$ & $4 \cdot 5$ & 225 & 195 \\
4 & $4 \cdot 2$ & $3 \cdot 4$ & 230 & 198 \\
\hline
\end{tabular}

The average serum cholesterol in eighteen cases was $250 \mathrm{mg}$. per cent. before treatment, 242 after Anturan, and 219 after Zoxazolamine.

Prothrombin Time.-Eighty estimations (shown as a percentage of the pre-treatment time) were carried out on the eighteen patients who were treated with Anturan and Zoxazolamine; the average was 99 per cent. after Anturan and 97 per cent. after Zoxazolamine. When series of estimations carried out on individual patients were reviewed, there appeared to be a slight initial fall when the patient first took Zoxazolamine, followed by a rapid return to normal within a week or two in the majority of cases.

\section{Subject Improvement and Side-Effects}

All patients claimed that they had improved rather than deteriorated during the 2 years, in that 
they were now having fewer attacks of gout and often had less general stiffness.

Eleven patients preferred Anturan. The reason was that they felt less "tired" and had less general stiffness and interval pain, probably because of the slight anti-inflammatory effect of this preparation.

Two patients preferred Urelim. One had developed boils while taking Anturan, but the white cell count remained normal and the boils did not recur on re-administration of Anturan. The other thought he had fewer attacks of gout while taking Urelim.

Of 21 patients who were transferred from Anturan to Zoxazolamine, five stated that they felt a "little tired" while taking the Zoxazolamine, one felt "muzzy" during the first 3 days of treatment, and one had slight headaches. Eight were equally well with either drug, but ten preferred Anturan and three Zoxazolamine.

Two patients had slight dyspepsia, but not sufficient to make one consider stopping medication during a minimum period of 6 weeks.

\section{Course of the Disease}

During the first 6 weeks of treatment there was a tendency to increase in the frequency of attacks of gout, but after this period there was marked lessening of frequency and severity. During this first 6 weeks, colchicine $0.5 \mathrm{mg}$. was given three times a day, and, if in spite of this, attacks occurred, phenylbutazone $600 \mathrm{mg}$. daily for 2 days was always completely successful in checking them.

In six instances there was a definite softening or decrease in the size of the tophi, and two patients reported some change in this direction after only 6 weeks' therapy.

\section{Summary}

32 patients with typical gout have been observed during treatment with uricosuric agents for at least 2 years, in continuation of the studies reported by Kersley and others (1958).

Anturan and Urelim were found to have a satisfactory effect both alone and in combination, and a similar effect was produced by the administration of Zoxazolamine.

Aspirin inhibited the uricosuric effect of all these drugs, but paracetamol did not do so.

Estimations were also made of the serum cholesterol and prothrombin times, with the idea of testing the theory that serum cholesterol and uric acid levels are related.

All the patients treated felt subjective benefit, although some felt better on one drug, and some on another. Toxic effects were rare and extremely slight, but on the whole Anturan was the favourite $\frac{\Phi}{3}$ drug and the least toxic.

Because the numbers of patients who could bees. tested with each drug varied, and only a few could $\rightarrow$ : be observed daily for months in hospital, these? results cannot collectively be subjected to statisticap analysis. They show clearly, however, the greato value, potency, and safety of the newer uricosuric drugs in the treatment of gout, with perhaps $\stackrel{\mathbb{\Omega}}{\Omega}$ Anturan leading the field. Further work is requiredow on the combined use of these drugs- e.g. the poten-tiation of Anturan by Urelim - and in particular on: the degree of inhibition exerted by various dosages $\vec{\omega}$ of other drugs, especially of the aspirin type. The possible importance of dosage inhibition is emphasized by the recent paper of Yü and Gutman ${ }_{\vec{\omega}}$ (1959).

We are indebted to Dr. W. S. Stoddart of Messrs.. Geigy Pharmaceutical Co. Ltd. for supplying theo Anturan, to Dr. J. M. Simister of Messrs. Ward Blenkin-? sop and Co. for the Urelim, and the McNeil Laboratories Inc. of Philadelphia for the Zoxazolamine.

\section{REFERENCES}

Burns, J. J., Yü, T. F., Berger, L., and Gutman, A. B. (1958). Amer $\stackrel{\mathbb{D}}{-}$

Gertler, M. M., and White, P. D. (1954). "Coronary Heart Diseêsরe in Young Adults." Harvard University Press, Cambrigge,

Mass.
Juergens, J. L., and Achor, R. W. P. (1959). Proc. Mayo Co

Kersley, G. D., Cook, E. R., and Tovey, D. C. J. (1958). Aming rheum. Dis., 17, 326. Kohn, P. M., and Prozan, G. B. (1959). J. Amer. med. Ass., $170 \frac{\partial}{1909 .}$

Lancet (1956). 1, 561 .

Reed, E. B., Feichtmeir, T. V., and Willett, F. M. (1958). NenD Engl. J. Med., 258. 894.

Thompson, G. R., Mikkelsen, W. M., and Willis, P. W. (1959) Arthr. and Rheum., 2, 383.

Yü, T. F., and Gutman, A. B. (1959). J. clin. Invest., 38, 1298.

\section{Agents uricosuriques dans la goutte}

RÉSUMÉ

A la suite des travaux rapportés par Kersley, Cook, et Tovey (1958), on a observé 32 malades atteints de goutte classique et traités par des agents uricosuriques pendantau moins deux ans.

Anturan et Urelim ont donné des résultats satisfaisants,

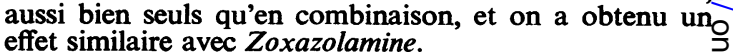

L'aspirine inhibait l'effet uricosurique de tous ces $D$ produits, mais le paracetamol ne l'inhibait pas.

On a procédé aussi à des déterminations du cholestérol sérique et du temps de prothrombine, pour vérifier la théorie qu'il y avait un rapport entre les taux de cholestérol sérique et d'acide urique.

Tous les malades traités ont accusé une amélioration subjective, bien que certains d'entre eux en préféraient unproduit à un autre. Des effets toxiques étaient rares et légers; en général, l'Anturan était le favori et le moinso toxique.

Comme le nombre de malades traités par chaque produit variait et peu d'entre eux pouvaient être observés tous les jours pendant des mois à l'hôpital, ces 
résultats, collectivement, ne se prêtent pas à l'analyse statistique. Ils montrent, toutefois, clairement la grande valeur, le pouvoir et l'inocuité des agents uricosuriques plus récents dans le traitement de la goutte, avec l'Anturan peut être à leur tête. D'autres travaux sont nécessaires sur l'emploi combiné de ces produits-par exemple la potentiation de l'Anturan par l'Urelim et, en particulier, sur le degré d'inhibition exercée par des doses différentes de certains médicaments, surtout ceux du type de l'aspirine. L'importance possible de la dose dans l'inhibition a été soulignée récemment par l'article de Yü et Gutman (1959).

\section{Agentes uricosúricos en la gota}

\section{SUMARIO}

Como una continuación de los estudios presentados por Kersley, Cook, y Tovey (1958) se han observado 32 enfermos con cuadro típico de gota en tratamiento con agentes uricosùricos por lo menos durante dos años.

Resultados satisfactorios se apreciaron con Anturan y Urelim, administrados solos o en combinación, y un efecto similar se produjo con Zoxazolamine.

La aspirina inhibe el efecto uricosùrico de estos productos, lo que no sucede con el paracetamol.
Se realizaron también determinaciones de colesterol sérico y tiempo de protrombina, con la idea de comprobar la teoría de la relación entre los niveles de colesterol sérico y ácido ùrico.

Todos los enfermos tratados experimentaron mejoría subjetiva, aunque algunos la apreciaron más con un determinado fármaco mientras que otros reaccionaron mejor a otro diferente. Efectos tóxicos fueron raros y leves, en general. Anturan fué el más preferido y menos tóxico.

Como el nùmero de enfermos tratados con cada fármaco varió, y solamente unos pocos pudieron ser observados diariamente durante meses en hospital, estos resultados no se pueden someter colectivamente a análisis estadístico. De todas formas, es claramente manifesto el gran valor, la potencia y la inocuidad de los ùltimos agentes uricosùricos introducidos en la terapéutica de la gota, con el Anturan quizá a la cabeza de ellos. Es necesario más trabajo sobre el uso combinado de estos productos (p.e. la potenciación del Anturan por el Urelim), y particularmente sobre el grado de inhibición ejercida por diferentes dosis de otros fármacos, especialmente del tipo de la aspirina. La posible importancia de la dosis en inhibición es subrayada por el reciente trabajo de Yü y Gutman (1959). 